\title{
The Extrinsic and Intrinsic Complexity of the Moroccan Family Firms: A Sociological Contextualization
}

\author{
Mohamed Farouk NASSIRI ${ }^{1} \quad$ Ahmed SABBARI $^{*}$ \\ 1. Faculty of Law, Economic and Social Sciences, Cadi Ayyad University (Marrakesh, Morocco). \\ 2. National School of Commerce and Management, Cadi Ayyad University (Marrakech, Morocco)
}

\begin{abstract}
As most of economies, the Moroccan one leans on family businesses to create growth and prosperity, yet these firms are particularly complexes organizations. Their complexity is mainly inherent to the divergent purposes of these firms and the nature of the Moroccan socio-cultural context that can be labelled as composite as well as several Arab-Muslim societies. Actually, Moroccan society is marked by an hybrid order of cultural values, negotiated permanently between tradition and modernity. In this chapter, we propose a sociological contextualization providing a discussion about the extrinsic and intrinsic complexity of Moroccan family businesses.After analyzing the characteristics of the family business as a complex system, we present the cultural traits of Moroccan society and family in this context. Finally, we address the issue of the implementation of sociocultural values in the managerial sphere and their implications for organizational behavior in family business. In light of this analysis, social responsibility practices and social relations within the Moroccan family business will be reviewed.
\end{abstract}

Keywords: family business, Moroccan context, culture, sociological approach, strategy

DOI: $10.7176 / \mathrm{EJBM} / 12-23-13$

Publication date:August $31^{\text {st }} 2020$

\section{Introduction}

What is the proportion of family businesses in the Moroccan economy? It is very difficult to give a satisfying answer to this question since statistics on the entrepreneurial phenomenon in general and in its various aspects including family entrepreneurship are still lacking. As a first approximation, one can reasonably estimate that in an emerging economy such as the Moroccan one, most of the businesses are family businesses or at least patrimonial.

The Moroccan press associate the concept of family business with major Moroccan groups that are controlled by families. These big groups are account alone for $30 \%$ of the national GDP. Yet the family nature of Moroccan firms is an even more deep-rooted phenomenon than that. Moroccan SMEs are basically familial. These companies represent over $90 \%$ of the economy and contribute to $50 \%$ of employment and $20 \%$ of the added value according to the Ministry of Industry and Trade of Morocco.

The ambiguity around the actual economic contribution of family businesses is coupled with the fragmented nature of the scientific knowledge produced in the theoretical field of family business. The issue of management of the family business is now one of the most intriguing topics of research in organizational sciences. In the research community, everyone talks about the specificity of family businesses but the answers on how specific these businesses are, are rare and not cumulative. According to Sharma, research in the field of family business will soon suffer from an undeniable lack in terms of new lines of research. Like any research field, the field of family business must be able to incorporate new ways of thinking to move forward (Sharma, 2006). The community of researchers have to be creative and innovative in its thinking and in the mobilized theories in research on family businesses. According to Lindblom and Cohen (1979), despite significant progress achieved in the theoretical corpus "family business", the field is still in its beginning and in a pre-paradigmatic struggle to win an autonomous conceptual identity (Hoy, 2003).

Research on family businesses highlights two cases. In the first, family businesses are receiving more and more interest from management researchers due to their dominance and impact on the socio-economic growth of nations. Another research stream highlights the research opportunity represented by such specific companies.

While it is true that the first situation still prevails in the literature, a call for a change in the approach remains and considers the family business as a case that allows studying the effect the permanence of the property has on the strategic business development.

In some cases, scholars consider that reflexion in the field of family business strategy is not only useful in itself, but also for exploring new aspects in research in strategic management in general (Jarzabkowski et al. 2007; Nordqvist and Melin, 2008; Whittington, 2006). The family business is a very promising in vivo research field for the whole field of management. Researchers now conclude that family businesses are specific cases of strategic management (Miller and Le Breton-Miller, 2005; Sharma et al., 1997). This specificity is expressed in part by the notion of "parallel planning" that evokes the need for simultaneous planning for the company and for the family to keep them both healthy (Carlock and Ward, 2001) but also by the notion of heritage and property. The latter 
would have profound effects on the strategy making.

The family business is probably the most complex form of entrepreneurial action to understand. The complexity of these companies is certainly intrinsic and extrinsic but is also conducted by the composite sociocultural contexts such as the Arab-Muslim societies. These companies are subjected to a range of hybrid cultural values, including an old traditional component and another coming from modernity. Another aspect of the inherent complexity of family businesses is related to the primary objectives of the business. Unlike the traditional model companies, whose main purpose is solely to maximize the benefit of its shareholders, family business includes other considerations into their priorities and practices by embracing their social and environmental responsibilities, looking for sustainability and the interest of the next generation of the family members.

The discourse and practices of the social responsibility have emerged in countries where respect for the law is clear, which is far from the case in Morocco even if things seem to be improving on this front. In such a context, it seems interesting to analyse the corporate social responsibility postures in in the light of cultural values of Moroccan family businesses.

Through the discussion of certain features of the family entrepreneurial act in Morocco, we will also try in this work to outline a first sociological portrait. This contribution focuses on a sociological analysis of the managerial and entrepreneurial act of family businesses in Morocco and shows how a sociological approach can help address the complexity of managerial conduct of family businesses in Morocco and clarify its special features.

\section{The peculiarity of the "complex" in the management of the family business}

The complexity is a way of thinking that distances itself from the classic scientist reasoning. This last, reduces phenomena to the direct consequences of their causes. According to this approach, there is no strict direct causality but complex dynamics. The concept of "dynamic" refers to the interaction between several organizational forces that give birth to the relevant issue. Consequently, we understand family business as a typical incarnation of the "complex system". It fulfils the required conditions to be understood as complex systems.

\subsection{Complexity of strategy in family business}

The family business is inherently complex. This idea is indubitably one of the main reasons the definition of family businesses remains problematic (Chrisman et al. 2003). The complexity of a system increases with the number of its components and their heterogeneity. According to Lambrecht and Lievens (2008), the roots of family businesses complexity are mainly the ownership, governance and the management. A family business owned by two families, for example, is much more complex than another wholly owned by a single family (Montemerlo, 2005). Gimeno and al (2010) show that the complexity is also generated by the overlay of two systems, family and organization. Furthermore, the complexity of the family depends on the number of members and branches within the family, their roles, their stories, their interests, etc. Succession is also an important source of complexity since it may engender exceptional strategic behaviors or decisions (Lansberg, 1999). Secondly, Gimeno et a.l (2010) explain how the complexity in family businesses increases with time because of the enlargement of the family and the business. Gimeno's recommendations are summarized in the need to develop ad hoc structures to reduce the complexity.

The complexity of family businesses has moreover an extrinsic origin: culture. Indeed, the cultural material held by the family in one hand and the rest of the social field in the business, has as main origin the ambient macrocultural environment. In a society as the Moroccan one, the level of complexity is remarkably noticeable. These societies are experiencing a coexistence between traditional values and others ascending by modernity.

According to Chrisman et al. (2003), the definition of the family business would shift towards an essencebased approach. Actually, we note that some authors focus on the influence of the family in the formulation of the strategy (Donnelley, 1964; Davis \& Tagiuri, 1989; Pratt \& Davis, 1986; Handler, 1989 Shanker \& Astrachan, 1996). Others insist that the deep essence of a family businesses is the profound will of the family to maintain control over the company even through the generations (Litz, 1995). Habbershon and al (2003) add the concept familiness that gathers all resources and unique and synergistic capabilities that are generated by the active presence of the family.

The synthesis made by Chrisman and al (2003) is particularly relevant to understand family businesses. Its work includes principally the definition of family businesses by its essence to give a general definition. Chrisman thinks that the following four points are inseparable and form the essence of the family business:

- The intention to maintain control of the ruling family coalition.

- The emergence of resources, unique and synergistic capabilities is inseparable from the involvement of the family.

- The underlying intention in the ruling family coalition to pass the business to the next generation.

- The furtherance of this intention through concrete measures.

This author gives the name "essence approach" to the definition he suggests as an alternative to the approach by "family involvement". The author considers that the approach by the involvement of the family is based on the 
assumption implicitly affirming that family involvement is a sufficient condition to talk about family businesses, whereas in the essence approach, the condition of the family involvement is necessary but not sufficient. The said approach adds that the family involvement must have effects in organizational behavior before giving the specific mention "family business" to the business. In other words, according to the approach of the "essence", two companies with the same degree of family involvement may not both be familial because of the family failure in some cases to produce a profound effect on the business. This is the definition we adopt as part of this paper. A family business is that if the family managed to produce a real impact on various organizational levels of the company including its social field.

This conception highlights the complexity of the family business. The inclusion of the family business complex character must have a conceptual reflection in any modeling endeavor that makes a break with the simplistic attitude that has long characterized the research doxa of the family business.

Despite of the extent of the research on the field "family business", we still facing a big lack of understanding on the complexity of the subject (Pieper and Klein, 2007). The analytic attitude is the major trait that characterizes the work on the family business so far. Attempts to bypass this major conceptual limit remain very exceptional. Pieper Klein states: "If the research field wants to take steps forward, we need a framework capable of framing a higher level of abstraction. At that time, we will be able to understand the properties and behavior of family businesses. This is crucial for a better determination of the emergence, evolution and survival of this particular type of business". (Peiper and Klein, 2007). The authors in this statement criticize the deficiency of abstraction that knows the search field. This epistemological flaw makes scholar's struggle to produce a synthesizing thinking and remain producing a fragmented knowledge. In its configurational typology of organizations and structures, Mintzberg (1979) distinguishes between two organizational models based on ownership and management control. The author describes as "simple" family SMEs and as "complex" major public companies or multinationals. Goffee (1996) questions this representation and stipulates that family businesses even when they are small, embody highly complex interrelationships between two analytically separate systems but very socially linked: the family and the business.

Piepper and Klein (2007) showed that the family business research trend to swings towards, what they called, third generation approaches that handles the complexity of the family business. Specifically, this step of research in family business has two main approaches: Family influence models and sustainable family business models. For Klein, it is the second models (sustainable family business models) that have the same degree of interest in the family as well as the business while providing a dynamic view of the phenomena (Danes, Rueter, Kwon, and Doherty, 2002; Stafford et al. 1999). These approaches also allow the use of diverse and novel theoretical perspectives, which make theme a real opportunity to propel the field forward.

This new trend, seeking to provide an advanced understanding of the family business must introduce in its analysis the relevant subsystems involved in the behavior of these companies: the environment; recognition of existing interactions between subsystems of family business and the environment; taking into account the time (dynamic view); the ability to integrate multiple levels of analysis (environmental groups, individuals ...) and finally the ability to integrate different theories from the literature on family business and organizational sciences.

\subsection{Organizational Specificity of the family business}

Many authors working on the construction of family business strategy believe that the main characteristic of this topic is the potential role of the family in this process. Apart from this aspect, the strategizing in family business remains similar to non-family businesses. However, most of these authors adheres to conventional current strategic management stream that reduces strategy to a set of formal practices starting from formulation of objectives followed by procedures and control (Harris et al. 1994; Sharma et al. 1997).

Other academics, insist on giving the family business a special status on the question of strategizing. According to Sandberg (1992): " firms that are family-owned, small or new are thought to be substantively unique in ways that make them special cases of strategic management." Agreeing to Melin and Nordqvist (2002), the family business tends to give priority to operational instead of strategic. On the other hand, she works incrementally on its strategic development and discusses some strategic opportunities as they arise rather than invest effort and time in the formal strategic planning. Habberson and Williams (1999) develop the concept of Familiness as the source of competitive advantage of the family business. The concept captures the idea that the family business holds a specific knowledge by the family members, abilities and skills that are developed over time through generations working in the business. By the same logic the work of Miller and Le Breton-Miller (2003) shows that this enterprise is an organization that gives attention to the development of organizational capacity of different levels. This means that the family business is committed to a multi-generational path dependency process dedicated to the development of cores capacities and organizational learning (Nordqvist, 2005). Another piece of literature on the specificity of the family businesses shows that the characteristics of the owners, their values and interests have a significant impact on the strategic issue (Harris et al. 1994; Dyer, 1994; Aronoff and Ward, 1995; Sharma et al. 1997). That is to say that there is also a big specificity in the family business in the formal aspects of the 
strategy: setting goals, the style of conducting processes and nature of the actors involved. The property has then a significant impact on the strategizing in the family business (Kets de Vries, 1993; Chua et al. 1999).

There is also another theme in literature showing some negative forces that family business has to manage (Hollander and Elman, 1988; Dyer, 1994; Upton and Heck, 1997). Hall (2002) summarizes this aspect by asserting that the family business is sometimes a victim of its irrational behavior. The company may neglect some formal management practices or behaves with less rationality because of the grasp of the aspirations of some family members. The multitude of subsystems may also exacerbate the conflict between the rational and the irrational causing states of inertia or failure (Levinson 1971). Poutziouris et al. (2004) sums up the negative aspects of the family business: introversion, conservatism, lack of professionalism and informal communication channels.

It is widely accepted that the social dynamics of the family business is the root of its organizational performance. It is an effective way to share knowledge internally. The degree of complicity between the active members of the family and the founder depends largely on this aspect (Kelly et al. 2000). Kelly et al. (2000) note that the role of the founder in a family business involves both formal and informal interactions with family and top management team. This interaction is almost permanent. Harris (1994) confirms this observation by assuming that the family business tends to rely primarily on informal procedures such as direct supervision, personal adjustment, informal communication channels, socialization, culture and shared values. The finding of Harris, confirms the thesis of the intrinsic complexity of the family business and that it behaves according to the fundamental logic of complex systems, that is to say, emergence instead of causality, sensitivity to the organizational micro-level (the social field, organizational routines and social practices) and the substantial influence of the environment. When we apprehend the family business as a complex system, the strategic behavior cannot be reduced to the formal decision-making by top management or to the vision of the director, but would be a complex organizational dynamics that takes root in the social field of business and forms overall behavior according to a logic of emergence (Mintzberg, 1979). On the other hand, the strategy of the family business is highly dependent on intra-process phenomena or organizational micro-foundations (Johnson et al. 2003).

Organizational micro-foundations are conceptual objects widely discussed in the approach of strategizing or theory of Strategy as Practice (Whittington, 1996; Jarzabkowski, 2004). These include practices, praxis, routines and the concept of dynamic capacity (Teece et al., 1997). Finally comes the substantial influence of the environment. The exchange with the environment does not refer only to the formal physical or functional level but refers essentially to the extrinsic complexity to the company emanating from the sociological context, as we will present in the following paragraph. In the Moroccan case, the composite order of values between traditionalism and modernism would be another major complexity vector. The social context is also the origin of several active objects in organizational micro-foundations (practices, routines, beliefs, etc). These organizational objects are crucial in the understanding of different organizational patterns in family businesses related to leadership, intraorganizational coordination, governance, etc.

\section{The family business in Moroccan cultural context}

\subsection{The Order of Composite Values in Moroccan Context}

The theories of the persistence of traditional values that affirms that the values of modernity are relatively vulnerable in developing countries, including Morocco. According to this view, modern values (usually Western) would literally grafts into the society by economic and cultural domination, colonization, and the pressures of international institutions, etc. We, then, come to what Paul Pascon1 called "a composite container of values" with a register for traditional values and another for those of modernity. In this composite model of society, there is coexistence between the tradition and the modernity.

Some values like "Niya" (i.e. trust), unconditional obedience to the father or that of the "Mektoub" (i.e. predestination) coexist with the sense of responsibility or rational calculation, etc. The aforementioned values from different origins blend in a complex cultural whole and even "unstable" (Bourqia, 2006). According to the latter, cultural changes in Moroccan society is neither positive nor negative. However, they respond to the rate of development of society and to the changes imposed by globalization. The fact is that traditional register of values is decreasing but without giving way entirely to modern and universal values, consequently that is what generate the complexity of the Moroccan society. As Pascon highlights, Moroccan society is hybrid in nature where the order of values is constantly negotiated between tradition and modernity.

The traditional model of the family and society is profoundly destabilized by modernity. However, for Todd (2006), the Arab family model, in general, and the one of the Moroccan family in particular is experiencing a much less violent transition comparing with the Russian or the Chinese model (Courbage and Todd 2006). According to the authors, the descriptions of the Russian peasantry point out a great "fury" against the father and against the family authority. This reactionary and violent social behavior has not failed to break violently the traditional values. Thus, the modernization process has led to a real disintegration of the community family. This aspect partly

${ }^{1}$ A Moroccan sociologist, considered as the founder of the Moroccan sociology. 
explains the violence of the Russian Revolution according to Todd. In contrast, the Arab-Iranian social systems, agreeing Todd and Courbage (2006), may seem significantly safer than the Russian system thanks to endogamy.

Actually, endogamous marriage enables the withdrawing of the family group on itself. This family behavior is thereby perceived as much less violent towards descendants. By contrary, in the Russian or the Chinese classic models, which are extreme cases, daughters may be used as alliances means between families and often abandoned by their families of origin. Thus, the Arab-Muslim model would be particularly protective towards women.

According to many social anthropologists, the Arab-Iranian model is a typical case of the transition to modernity. This transition is anything but a forceful rupture toward the legacy of the traditional era. Todd and Courbage (2006) consider that inside these societies, some population segments still hold nostalgia for the community way of life and the patriarchal values of the past. This nostalgia is explained on one hand by the fact that the family in these societies is warmer and more protective, and on the other hand, because of the patriarchal authority that is not as repressive or sadistic as what we may find in the image of Russian or Chinese of fathers.

Moreover, being part of the Arab-Iranian general, the Moroccan family model combines other features (Todd, 2006). Anthropological studies on Moroccan society suggest some contradictory aspects: coexistence between a classical Arab family system (community, patrilocal and endogamy), and the persistence of some Berber values considered as advantageous toward women. Todd's point is based on the index of patrilocality and matrilocality that measures the intensity of masculine dominance in the system of kinship. By the way, matrilocality is the tendency of young couples to settle on the side of the wife's family. Urban matrilocality in Morocco in 1982 is $12.3 \%$ while in Syria (average Arab countries) was 5.2\%.

\subsection{Beyond the Family, the "Kinship"}

Practically, every socio-anthropological research on the North African family in general and Moroccan families in particular, goes on the same run to recognize the strength of this institution despite serious damages resulting from several social phenomena such as migration, marital breakdown or the decline of traditional values.

While it is true that cultural and demographic changes actively contribute to the transformation of the family in its traditional form, the Moroccan family has not failed to generate its own defensive mechanisms. The traditional form of the Moroccan family loses place but kinship ties are still strong.

Many Moroccan anthropologists and sociologists (e.g. Bourqia, Tozy, Benchrifa) prefer the concept of "kinship" to that of "family" to study blood ties in the Moroccan social field. Kinship is defined as the way in which people are related by birth or through marriage in different societies, paying more attention to the different formation mechanisms of matrimonial relations as well as mechanisms establishment and groups' transmission of cultural knowledge through the generations.

As in most Arab societies, the family institution is significantly different from what it was a generation ago. Initiated by colonization, changes in Moroccan society are continuing with the effects of urbanization, audiovisual communication, schooling, gender diversity at school, women's entry into the job market, men's emigration and family planning (Ben Salem, 1981). Moroccan family unit is so deeply influenced. The traditional system based on joined possession of lands and self-sufficiency become separated from the production function and leaves the strictly family frame. Culturally, the hierarchical family, patriarchal, authoritarian and extended model is losing even more. The family also ceases to be the sole repository of values because of the rise of other rival social institutions (schools, labor unions, political organizations) (Kerrou and Kharoufi, 1994).

However, the Moroccan family institution has developed forms of adaptation by mixing between many traditional values with the new modern cultural trends. The National Family Survey conducted by the Moroccan HPC (High Planning Commission) shows that values such as honor, respect, mutual assistance, and solidarity remain largely preserved. The extended family is always present at major events such as marriages, divorces, deaths, and religious holidays or during periods of crises. According to this survey, the theory which states the vision of linear evolution from a form of extended family to nuclear one is questionable. Moroccan nuclear family would be intrinsically different from "isolated conjugal" families of the West. Despite its nuclear character, modern Moroccan family would always be rooted in a solidary kinship network that includes the ascendants, descendants and collaterals.

According to many Moroccan anthropologists, the extended kinship replaces the extended family. The kinship would then be a particularly active property in Morocco because it manages to expand to a higher number of ascendants, descendants, and collateral, contrary to the state of things in the western countries where the kinship remains largely latent and limited. As indices, confirming the thesis of the strength of family ties in Moroccan society, statistics show that loans and grants are widely traded between households belonging to the same kinship. Donations would even be doubly more frequent because of the strength of family solidarity ideology. On the other hand, according to the households surveyed by the HPC, direct meetings with parents and grandparents still the most used means to get their news, despite the high availability of means of communication. The ties of solidarity between households go beyond the scope of the patrilineality or those of the matrilinearity to reach the parents of the husband as well as of the wife. 
The study which we briefly present the results also displays clearly the will of Moroccan households to expand their field of "active kinship" even beyond the strict parental ties. This quest for active kinship is stimulated by the challenges of modern social life, contrary to what one might see in Western society. However, the intensity of solidarity links becomes weaker proportionally with the distance from the immediate family circle (parents, children, siblings).

\section{A sociological approach towards a renewed perception of the particularities of Moroccans Family Business}

\subsection{The transposition of the socio-cultural values in the managerial sphere}

According to Allali (2008), Moroccan society is governed by strong values that contribute heavily even in restricted social fields including entrepreneurship and business field. According to the author, it is clear that the order of social values is a strong pillar in the practice of management in the Moroccan firm. The logic of allegiance, the familism and the sacredness of dignity are listed by the author as the basic cultural pillars that dictate the Moroccan management style.

a. The logic of allegiance

This value is rooted in the spiritual foundations of Morocco "Islam." The word Islam is synonymous with submission and obedience. Sacred texts calling believers to obey their Emirs are very numerous. The logic of allegiance is further strengthened by the monarchy, which is one of the oldest in the world. The ties of allegiance have been strengthened by the monarchical regime both politically and religiously through the "Commander of the Believers" status and the fact that the kings of Morocco have the privilege of being the Prophet's descendants. The logic of allegiance has also influence in the body of the Moroccan society beyond its formal character. People are consciously or unconsciously induced to obey others as they embody on their eyes uprightness and integrity to be worthy of obedience (Allali, 2008) and the righteousness of the leaders is rewarded by the loyalty of followers. D'Iribarne (1998) notes the full involvement of SGS-Thomson Casablanca workers in their work and that they even exceed the targets set by the office of the company. This behaviour is explained primarily by the value of allegiance that Moroccan testifies to anyone who is worthy.

b. The Familism

According to Allali (2008), the dimensions of individualism and collectivism defined by Hofstede (1987) do not apply to the Moroccan context. According to the author, very few Moroccans would be defined as individualistic in the sense of Hofstede, because they are rarely motivated by self-interest. Similarly, collectivist character is also not very suitable to the behaviour of Moroccans since the community's interest is not really an urgent imperative. So, between individualist and collectivist in the sense of Hofstede, Allali thinks the Moroccan is essentially a familialist. The family of a Moroccan comes first. It is common for Moroccans to make sacrifices to ensure the education of their children or do practices at the limits of what is legal to allow an unemployed son to immigrate or to find a job. Familism also plays the role of defensive behaviour of society towards the problems of employability and financial instability of households. Moroccan parents never get tired of their children regardless of their age if they are forced to stay in their father's house due to lack of employment.

Moroccan regional cultures do not strictly respect this principle of familism. Some anthropological studies show that the population of "Souss" in the southern region are more attached to the community in contrast to the region of "Fes" where people are a little more individualistic. The concept of family is broader among the population of " Souss ". It also includes grandparents, cousins, aunts, uncles, grandchildren or even the tribe or the clan.

c. The sacredness of dignity

Respect for dignity is central to the behavior of the Moroccan. When working conditions are lacking dignity, the Moroccan react at the first opportunity to reaffirm his commitment to dignity, one way or another. Conversely, when respected and valued, the Moroccan may show levels of involvement and remarkable dedication. The study of D'Iribarne on culture and the implementation of TQM at SGS-Thomson Casablanca confirms this analysis.

\subsection{The ambiguity of CSR posture in the EFM}

a. The social dimension of family CSR: social policy and labor relations

In the first approach, and on an institutional level, we can highlight that the social dimension focuses more on discussions between employers, unions and governments. The focus on themes is related to social dialogue, the employment relationship and working conditions, during the last assizes of CSR, organized in Casablanca, attests to the significance of the social question in the business. It seems that following the social movements experienced by the Arab countries, employers and leaders are increasingly engaged in this extremely delicate political environment, which is reflected in business. "the protest movement are not only in the streets, they are also in business", noted one observer HR practices in Morocco.

Nevertheless, this mobilization is also related to the size of the deficit in social policy particularly in family SMEs. Social commitment is not however totally absent. In fact, in practice, family leaders can demonstrate an unwavering commitment to their employees in specific situations or events (hospitalization of the employee or a 
family member, death, marriage ...) while their statutory rights are not fully respected. This behaviour, which seems paradoxical, can be explained by the need for these leaders to guarantee recognition of employees and therefore their allegiance.

The deployment of formal approaches to social responsibility seems indeed stumbling across several obstacles. In Morocco, a first factor seems to be related to the place of this dimension in the strategy of family businesses. By referring to the speeches of the leaders of family businesses, it can be concluded that social engagement is not inscribed in a perspective of social attractiveness and employee satisfaction. This commitment is rather a risk control of social conflicts and risks of non-conformity to national or international standards. A relative change is however underlined. For example, deployment of quality assurance policies and certification programs bring more and more family businesses to set up training programs in a logic of long-term competitiveness. In some cases, modernization of production tools poses the urgency of literacy programs for the personnel.

This social insecurity must also be put into perspective with the fragmented nature of the national economy and economic insecurity of Moroccan family businesses. Aboudrar (2002) expresses this idea when he emphasizes that "CSR raises a legitimate question of financing social costs". In addition, for many observers, compliance with labour law gets better in large family firms than in small ones, due to the type of organization they require. However, it seems that as the competitiveness of the company is based on the unskilled labor force, employment and remuneration conditions prevailing there prove to be poor. Thus, more than the size, the level of skills and knowhow required seems to influence the degree of structuring of the organization and the quality of social relations in the family business.

Finally, the move towards the western model of CSR seems related to a number of complex factors including the intensity of integration into the formal economy, the size of the organization, the quality and availability of labor-force, the degree of openness to foreign markets, etc.

\section{b. Societal policies and relations with stakeholders}

The societal dimension is now an integral part of the internal processes of enterprises and purposes of the management in terms of CSR. The issue of "stakeholders" is a fundamental dimension, referring to the European design, in the exercise of CSR should first perform within the organization and in respect of stakeholders. The concept is now presented as a management tool and a representation pattern of the firm vis-à-vis its environment. The stakeholders of the firm are typically made by its employees, customers, business partners, public authorities and in the enlarged representation by other local actors that affect or are affected by the activities of the business.

In the Moroccan context, it is clear that the practices of family businesses tend to build social responsibility aligned with the requirements of foreign partners. In this configuration, partners and local people do not actually reach the status of "stakeholder". CSR is exercised according to the image that the firm must send to its customers and the imposed norms. Several experts interviewed recognize, however, that the participation of family businesses in development activities in Morocco is an established practice well before the movement of sustainable development and CSR. Social responsibility is exercised still largely on the figure of the leader entrepreneur, as a wealthy person or family more than the company.

The report of family enterprises to CSR and precarious societal policies that remains most often discretionary must be put in perspective with the commitment valuation of opportunities in the market. Following Meknassi Filali (2010), for a large part of entrepreneurs and family businesses, the success in the domestic market is essentially dependent on the success of their products. Even if the businesses reputation is a major concern for those who market their products under brand names, in a market won by consumerism, costumers remain more attentive to the value of goods and services offered to them than the conditions under which they were obtained. Thus, social commitment, respect for the environment or the fundamental rights do not seem to be decisive selling points for Moroccan family businesses.

\section{c. Environmental policies}

Despite the growing mobilization of the voluntary sector and the involvement of some state agencies in environmental issues in recent years, policies and commitments of Moroccan family businesses shows little progress. The consideration of environmental issues is facing major challenges and constraints at different levels. At the regulatory level, some leaders evoke a lack of consistency in environmental public policy and a lack of transparency and accuracy in regulation. Following this perspective, there would be an environmental policy at two speeds: on one side, a regulatory policy increasingly firm vis-à-vis some large structured industries (oil refineries, power plants, cement plants) whose activity subject to European standards, on the other hand, there is an almost total absence of rigour on other less structured activities, particularly small and medium industries.

Compliance and respect of regulations by businesses is also facing other major problems. A major problem is the cost of combined remediation technologies and processes in the absence of environmental infrastructure to handle water management problems and waste, despite the efforts already made by the government in large urban centres. The sanitation sector as well as that of the waste management (collection, sorting, recovery, and storage) are serious obstacles to the deployment of environmental policies. 
Several leaders of family businesses surveyed, however, are willing to get involved in environmental preservation policy, including in financial terms but in return want to be recognized by the public authorities with an 'environment' label, incentives tax, grants to acquire the equipment necessary to reduce their environmental impact (waste, emissions ...). Some Moroccan family firms have even developed a new business from these environmental issues. They now offer flexible and often innovative solutions to meet the diverse needs on behalf of businesses and local authorities, including the management of industrial waste (paper, wood, cardboard, glass, rubble) or industrial waste (asbestos, hydrocarbons, solvents) for SMIs.

In general, as to environmental issues, the leaders of family businesses seem sensitive to environmental problems, but the commitment in structured approaches remains dependent on state involvement and the availability of resources and necessary infrastructure.

\section{Conclusion}

The informality of the economy is strongly correlated with the communitarian nature of the entrepreneurial act, whereas the production unit is indissolubly linked to the family. The communitarian aspect provided the firm -in under formalized economies - an guarantee against the threatening uncertainty. These firms, in a country like Morocco, are then more communitarian and traditional rather than individualist and modern.

In such a landscape, Moroccan family business appears to have a management system with strong socio-cultural roots. However, the statement that values are settling in the heart of the identity of the firms seems having some troubles of verification. Moroccan family businesses are characterized by a very ambiguous CSR posture where sensitivity to social and environmental issues, even if it is present, remains weakly structured and often informal.

Family businesses are the most common form of the firm and represent the major part of nearly all national economies. This preponderance is paradoxically associated with a lack of knowledge, or at least a conceptual distortion that characterizes the academic research in this area.

In general, research in the field of family business must be able to integrate new ways of thinking to go forward (Sharma, 2006) and to earn a real autonomous conceptual identity instead of staying in this undeniable lack of new lines of research.

It is because of the difficulty to separate the family business from the family, and the inconceivability to understand family dynamic without reference to the social value system; sociological approaches seem so inevitable to revolutionize the field of research in family business. These approaches may provide new frameworks that would be able to integrate the complexity coming from both intrinsic and extrinsic environments relating to family businesses.

\section{References}

Aboudrar A. (2002). Ethique et Responsabilité sociale de l'Entreprise, les ingrédients de la modernité. In Mezouar A. (dir.), "L'entreprise marocaine et la modernité. Recherche sur les conditions de changement culturel pour un progrès durable ", Edit CRD (Centre d'Etudes et de Recherche des Dirigeants), pp. 99-107.

Allali, B. (2008). Culture et gestion au Maroc: une osmose atypique. Gestion en contexte interculturel: approches, problématiques, pratiques et plongées. Québec, Presses de l'Université Laval et Télé-université (UQAM), 136.

Amagoh, F. (2008). Perspectives on Organizational Change: Systems and Complexity Theories, 13(3), 1-14.

Anderson, P. (2008). Complexity Theory and Organization Science, 10(3), 216-232.

Aronoff, C. E., \& Ward, J. L. (1995). Family-Owned Businesses: A Thing of the Past or a Model for the Future?. Family Business Review, 8(2), 121-130.

Astrachan, J. H. (2010). Strategy in family business: Toward a multidimensional research agenda. Journal of Family Business Strategy, 1(1), 6-14.

Ben Salem, L. (1989). Structures et caractéristiques des familles au Maroc, 26-39.

Bhalla, A., Lampel, J., Henderson, S., \& Watkins, D. (2007). Exploring alternative strategic management paradigms in high-growth ethnic and non-ethnic family firms. Small Business Economics, 32(1), 77-94.

Blaauw, M. (2005). Challenging contextualism. Grazer Philosophische Studien, 69(1), 127-146.

Bourqia, R. (2006). Les valeurs : Changements et perspectives, 61-104.

Bourqia, R., Bencherifa, A. \& Tozy, M. (2007). Rapport de synthèse de l'enquête nationale sur les valeurs. 50 ans de Développement humain, Perspectives 2025.

Brendel, E., \& Ja, C. (2004). Contextualisms in Epistemology Edited by (Vol. 3).

Brown, S. L., \& Eisenhardt, K. M. (2010). The Art of Continuous Change: Linking Complexity Theory and Timepaced Evolution in Relentlessly Shifting Organizations, 42(1), 1-34.

Brundin, E., \& Kjellander, B. (2010). Strategy Formation in the Family Business: The Role of Storytelling. Journal of International Business Studies.

Brundin, E., \& Melin, L. (2006). Unfolding the dynamics of emotions: how emotion drives or counteracts strategising, 1(3), 277-302. 
Buchanan, D. a., \& Bryman, a. (2007). Contextualizing Methods Choice in Organizational Research. Organizational Research Methods, 10(3), 483-501.

Carlock, R., \& Ward, J. (2001). Strategic planning for the family business: Parallel planning to unify the family and business. Springer.

Chirico, F. (2007). Improving the long-run survival of family firms: Knowledge-management and resourceshedding processes (Doctoral dissertation, University of Jyväskylä, Finland).

Chirico, F., Nordqvist, M., Colombo, G., \& Edoardo Mollona. (2012). Simulating Dynamic Capabilities and Value Creation in Family Firms: Is Paternalism an "Asset" or "Liability"?, 1-42.

Chrisman, J. J., Chua, J. H., \& Steier, L. P. (2003). An introduction to theories of family business. Journal of business venturing, 18(4), 441-448.

Chrisman, J. J., Chua, J. H., \& Sharma, P. (2003). Current trends and future directions in family business management studies: Toward a theory of the family firm. Coleman white paper series, 4, 1-63.

Chua, J. H., Chrisman, J. J., \& Sharma, P. (1999). Defining the family business by behavior. Entrepreneurship: Theory and Practice, 23(4), 19-19.

Coche, C. (2009). Structures familiales et gouvernement de l'entreprise familiale. In Communication à la 18 ème Conférence de l'AIMS, du (Vol. 28).

Courbage, Y., \& Todd, E. (2007). Le rendez-vous des civilisations. Seuil.

Danes, S. M., Rueter, M. A., Kwon, H. K., \& Doherty, W. (2002). Family FIRO model: An application to family business. Family Business Review, 15(1), 31-43.

Davis, J. A., \& Tagiuri, R. (1989). The influence of life stage on father-son work relationships in family companies. Family Business Review, 2(1), 47-74.

Dawson, A., \& Hjorth, D. (2011). Advancing Family Business Research Through Narrative Analysis. Family Business Review, 25(3), 339-355.

Derose, K. (1999). Contextualism: An Explanation and Defense, 1-26.

Donnelley, R. G. (1964). The family business. Harvard Business Review, 42(4), 93-105.

Dyer, W. G., \& Handler, W. (1994). Entrepreneurship and family business: Exploring the connections. Entrepreneurship Theory and Practice, 19, 71-71.

Dyer, W. G. (2006). Examining the "Family Effect" on Firm Performance. Family Business Review, 19(4), 253273.

D’Iribarne, P. (1998). Les ressources imprévues d'une culture: une entreprise 'excellente'à Casablanca. D'IRIBARNE P. et al. (1998), Cultures et mondialisation. Gérer par-delà les frontières, chapitre IX, 225-253.

Eisenhardt, K. M., \& Piezunka, H. (2011). Complexity theory and corporate strategy. The SAGE handbook of complexity and management, 506-523.

Emirbayer, M., \& Johnson, V. (2008). Bourdieu and organizational analysis. Theory and Society, 37(1),

Frank, H., Lueger, M., Nosé, L., \& Suchy, D. (2010). The concept of "Familiness.” Journal of Family Business Strategy, 1(3), 119-130.

Franz W. Kellermanns Kimberly A. Eddleston. (2006). Corporate Entrepreneurship in Family Firms: A Family Perspective, (662), 809-830.

Filali Meknassi R. (2011). La réceptivité des entreprises à la RSE - Quelques considérations à la lumière de l'expérience marocaine. In Daugareilh I., Coll., Responsabilité sociale de l'entreprise transnationale et globalisation de l'économie, Bruylant (Emile), 864 p.

Goffee, R. (1996). Understanding family businesses: issues for further research. International Journal of Entrepreneurial Behavior \& Research, 2(1), 36-48.

Gomez, M. L. (2010). A Bourdieusian perspective on strategizing. Cambridge handbook of strategy as practice, 141-54.

Habbershon, T. G., \& Williams, M. L. (1999). A Resource-Based Framework for Assessing the Strategic Advantages of Family Firms. Family Business Review, 12(1), 1-25.

Habbershon, T. G., Williams, M., \& MacMillan, I. C. (2003). A unified systems perspective of family firm performance. Journal of business venturing, 18(4), 451-465.

Hall, A. (2002). Towards an understanding of strategy processes. In D. E. Fletcher (Ed.), Understanding small family business (pp. 32-45). New York: Routledge.

Handler, W. C. (1989). Methodological issues and considerations in studying family businesses. Family business review, 2(3), 257-276.

Harris, D., Marinez, J.I., Ward, J.L., 1994. Is strategy different for the family-owned business? Fam. Bus. Rev. 7 (2), $159-174$.

Hofstede, G. (1987). The cultural context of accounting. Accounting and culture, 1-11.

Hollander, B. S., \& Elman, N. S. (1988). Family-Owned Businesses: An Emerging Field of Inquiry. Family business review, 1(2), 145-164. 
Holmdahl, L. (2005). Complexity Theory and Strategy, a Basis for Product Development, 1-37.

Jarzabkowski, P. (2004). Strategy as practice: recursiveness, adaptation, and practices-in-use. Organization studies, 25(4), 529-560.

Jarzabkowski, P., Balogun, J., \& Seidl, D. (2007). Strategizing: The challenges of a practice perspective. Human relations, 60(1), 5-27.

Johnson, G., Melin, L., \& Whittington, R. (2003). Micro strategy and strategizing: towards an activity-based view. Journal of management studies,40(1), 3-22.

Kelly, L. M., Athanassiou, N., \& Crittenden, W. F. (2000). Founder centrality and strategic behavior in the familyowned firm. Entrepreneurship Theory and Practice, 25(2), 27-42.

Kerrou, M., \& Kharoufi, M. (1994). Maghreb: Familles, valeurs et changements sociaux. Monde arabe: Maghreb Machrek, (144), 26-39.

Kets de Vries, Manfred F.R. (1993), Leaders, Fools and Impostors, San Francisco: Jossey Bass.

Klein, S. B. (2010). Corporate Governance, family business complexity and succession, 1-20.

Lambrecht, J., \& Lievens, J. (2008). Pruning the family tree: An unexplored path to family business continuity and family harmony. Family Business Review,21(4), 295-313.

Lansberg, I. (1999). Succeeding generations: Realizing the dream of families in business. Harvard Business Press.

Levinson, H. (1971). Conflicts that plague family businesses. Harvard Business Review, 49(2), 90-98.

Levy, D. L. (1996). Applications and Limitations of Complexity Theory in Organization Theory and Strategy, (1 990).

Lichtenstein, B. B. (2000). The matrix of complexity: A multi-disciplinary approach for studying emergence in coevolution. Mobilizing the self-renewing organization: The co-evolution advantage. SAGE Publications, forthcoming. 1-34

Lindblom, C. E., \& Cohen, D. K. (1979). Usable knowledge: Social science and social problem solving (Vol. 21). Yale University Press.

Litz, R. A. (1995). The family business: Toward definitional clarity. Family Business Review, 8(2), 71-81.

Mason, R. B. (2007). The external environment's effect on management and strategy: A complexity theory approach. Management Decision, 45(1), 10-28.

Mckelvey, B. (2002). Complexity Theory in Organization Science: Seizing the Promise or Becoming a Fad? Bottom-Up Organization Science, 1(1), 1-10.

Miller, D., \& Le Breton-Miller, I. (2005). Managing for the long run: Lessons in competitive advantage from great family businesses. Harvard Business Press.

Mintzberg, H. (1979). An emerging strategy of" direct" research. Administrative science quarterly, 24(4), 582-589.

Mjøset, L. (2008). The Contextualist Approach to Social Science Methodology. S, 39-68.

Montemerlo, D. (2005). Family ownership: Boost or obstacle to growth. In FBN-IFERA World Academic Research Forum, EHSAL Brussels.

Morrison, A. (2006). A contextualisation of entrepreneurship. International Journal of Entrepreneurial Behaviour \& Research, 12(4), 192-209.

Nordqvist, M. (2005). Familiness in top management teams: Commentary on "An exploratory comparison of the behavioral dynamics of top management teams in family and nonfamily new ventures: Cohesion, con- flict, potency, and consensus." Entrepreneurship Theory and Practice, 29, 285-291.

Nordqvist M. (2005). Understanding the role of ownership in strategizing: A study of family firms, $\mathrm{PhD}$ dissertation, Jonkoping International Business School.

Nordqvist, M. (2011). Understanding strategy processes in family firms: Exploring the roles of actors and arenas. International Small Business Journal, 30(1), 24-40.

Nordqvist, M., \& Melin, L. (2010). The promise of the strategy as practice perspective for family business strategy research. Journal of Family Business Strategy, 1(1), 15-25.

Nordqvist, M., Hall, A., \& Melin, L. (2008). Methodology and Family Business Studies: The Interpretive Approach. Nordqvist, M., \& Melin, L. (2002). 6 The dynamics of family firms.Understanding the small family business, 94 .

Parada, M. J., Gimeno, A., \& Melin, L. (2010). Familiness: An Asset or a Liability.

Pascon, P. (1980). Études rurales: idées et enquêtes sur la campagne marocaine. Société marocaine des éditeurs réunis.

Pieper, T. M., \& Klein, S. B. (2007). The bulleye: A systems approach to modeling family firms. Family Business Review, 20(4), 301-319.

Poutziouris, P., Steier, L., \& Smyrnios, K. (2004). Entrepreneurial developments in the family business. International Journal of Entrepreneurial Behaviour and Research, 10(1).

Publications, S. (2012). Society Made Visible- on the Cultural Sociology of Pierre Bourdieu, 25(2), $103-115$.

Rachik, H. (2007). L'Islam au quotidien : enquête sur les valeurs et les pratiques religieuses au Maroc. Marsam Editions.

Rotmans, J., \& Loorbach, D. (2009). Complexity and Transition Management. Journal of Industrial Ecology, 13(2), 
184-196.

Sâadi, M.S. (1982). Éléments d'analyse des entreprises personnelles et familiales marocaines, Gestion et Société, no 9 , p. 65-75.

Sandberg, W. R. (1992). Strategic management's potential contributions to a theory of entrepreneurship. Entrepreneurship: Theory and Practice, 16(3), 73-91.

Schneider, M., \& Somers, M. (2006). Organizations as complex adaptive systems: Implications of Complexity Theory for leadership research. The Leadership Quarterly, 17(4), 351-365.

Shanker, M. C., \& Astrachan, J. H. (1996). Myths and realities: Family businesses' contribution to the US economy-A framework for assessing family business statistics. Family Business Review, 9(2), 107-123.

Sharma, P., Chrisman, J. J., \& Chua, J. H. (1997). Strategic management of the family business: Past research and future challenges. Family business review,10(1), 1-35.

Stafford, K., Duncan, K. A., Dane, S., \& Winter, M. (1999). A research model of sustainable family businesses. Family Business Review, 12(3), 197-208.

Stafford, K., Danes, S. M., \& Haynes, G. W. (2013). Long-term family firm survival and growth considering owning family adaptive capacity and federal disaster assistance receipt. Journal of Family Business Strategy, 4(3), 188-200.

Tagiuri R. \& Davis J. A. (1996). Bivalent Attributes of the Family Firm”, Family Business Review, vol. 9, n 2 , 199-208.

Teece, D. J., Pisano, G., \& Shuen, A. (1997). Dynamic capabilities and strategic management. Strategic management journal, 509-533.

Tsoukas, H., \& Hatch, M. J. (2008). Complex thinking, complex practice: The case for a narrative approach to organizational complexity, 54(200108), 979-1013.

Upton, N., Heck, R., 1997. The family business dimension of entrepreneurship. In: Sexton, D.L., Smilor, R.W. (Eds.), Entrepreneurship 2000. Upstart, Chicago, IL, 243 - 266.

Weininger, E. B. (2005). Foundations of Pierre Bourdieu's class analysis.Approaches to class analysis, 82-118.

Whittington, R. (2006). Completing the practice turn in strategy research.Organization studies, 27(5), 613-634.

Whittington, R. (1996). Strategy as practice. Long range planning, 29(5), 731-735.

Zellweger, T. M., Eddleston, K. a., \& Kellermanns, F. W. (2010). Exploring the concept of familiness: Introducing family firm identity. Journal of Family Business Strategy, 1(1), 54-63. 